\title{
Resources of the Manchurian pheasant (Phasianus colchicus pallasi) in the Amur region
}

\author{
Aleksandr Toushkin ${ }^{1, *}$, Alia Toushkina ${ }^{1}$, Olga Matveeva ${ }^{1}$, and Aleksandr Senchik ${ }^{1}$ \\ ${ }^{1}$ Far Eastern State Agrarian University ,86, Politeknicheskaya Str., Blagoveschensk, Russia
}

\begin{abstract}
This article is based on the materials of long-term (2000-2019) data of winter route census (WMA) of the Manchurian pheasant population inhabiting the Amur Region. The main limiting factors causing fluctuations in the number of these bird species have been identified. The spatial distribution of birds by habitat within the range in the study area is considered. In winter, the main ecological factors that determine the features of the spatial distribution and the success of wintering of grouse birds in a sharply continental climate with monsoon features are the presence and abundance of available food and the state of the snow cover. In some cases, it is deep snow that determines the success of bird wintering. At night, at extremely low temperatures and strong winds, birds die from a lack of snow cover: either the snow cover is not deep enough, or a crust is formed (when thawing / due to wind). In the spring-summer period, the main limiting factors for birds that survived the winter are weather and climatic conditions that affect the survival of clutch and young stock; natural emergencies (fires, floods, floods, etc.), diseases, anthropogenic factors, etc.
\end{abstract}

\section{Introduction}

The hunting economy is an important component of the economy of the Russian Federation. Hunting organizations increase the employment of the population, pay taxes to the budget and provide the population with meat and wild products. The resources of hunting animals play an important role in providing the population of our country with ecologically clean meat products, which is important given the growing population of our planet and the deteriorating environmental situation. The rational use of hunting resources is unthinkable without an analysis of the state of species populations, which is carried out on the basis of long-term data on the dynamics of the number and use of animals.

* Corresponding author: toushkin@list.ru 


\section{Materials and methods}

The investigations by the authors were carried out in the Amur Region, mainly in the central and southern parts of it on the territory of the Zeisko-Bureya Plain, where the bulk of the Manchurian pheasant (Phasianus colchicus pallasi) population in the region lives. The Zeya-Bureinskaya plain (area about 4 million hectares) is located on the left bank of the Middle Amur and occupies the territory between the Amur, Zeya, Selemdzha rivers, Turana and Bureinsky ridges. On the territory of the plain there are 14 administrative districts of the Amur Region: Belogorsky, Zavitinsky, Ivanovsky, Konstantinovsky, Mikhailovsky, Oktyabrsky, Romnensky, Seryshevsky, Tambovsky, as well as parts of the districts: Arkharinsky, Bureysky, Blagoveshchensky, Mazanovsky and Selemdzhinsky.

The climate of the Zeya-Bureya Plain is continental with monsoon features. Winters with little snow, the average height of the snow cover is $15-20 \mathrm{~cm}$. The spring is cold, dry and long. Summers are warm and humid. Autumn is warm, but the average daily temperature drops sharply [7]. Weather factors during the growing season contribute to the rapid growth of vegetation. The main forest-forming species are larch, pine, oak, birch; in the south, there are Amur velvet, Manchurian walnut, ash, linden, etc. The most common shrubs are wild rosemary, rhododendron, Manchurian hazel, and Middendorf birch. Forest communities are severely disturbed. At present, about $80 \%$ of the territories of the ZeyaBureya Plain are occupied by anthropogenic landscapes [3, 13]. Most of the ZeiskoBureninskaya plain is occupied by crops of grain and legumes. Trees and shrubs on the Zeya-Bureinskaya plain are located in the form of small reeds (islets) in the middle of stretching agricultural fields. All this creates rather stable favorable conditions for many bird species [16].

The research is based on an analysis of the state of the number and use of the Manchurian pheasant population in the hunting grounds of the Amur Region. Data on the number of pheasants were taken from reports on the results of winter route counts of game animals in the hunting grounds of the Amur Region. The analysis of the use of the species population was carried out on the basis of reports from game users on the use of hunting resources.

\section{Results}

The natural range of the common pheasant (Phasianus colchicus Linnaeus, 1758) is quite extensive. The species is distributed from southeastern Europe in the west to Kamchatka in the east and from eastern Siberia in the north to Indochina and Afghanistan [4, 5, 9, 15]. The species is acclimatized in Europe, North America, Japan, New Zealand, and Australia $[8,15]$. There are 30 subspecies of common pheasant in the world $[8,9,15]$, two subspecies live in Russia [9], in the Far East there is one subspecies - the Manchurian pheasant (Phasianus colchicus pallasi Rothschild, 1903) [6, 9]. The Manchurian pheasant (Phasianus colchicus pallasi Rothschild, 1903) belongs to the Chinese type of fauna [14].

On the territory of the Amur Region, most of the population of the Manchurian pheasant (Phasianus colchicus pallasi Rothschild, 1903) lives within the Zeisko-Bureya plain [11, 12, 17]. The largest area of land suitable for habitation of the Manchurian pheasant is located on the territory of 10 central and southern regions of the Amur Region: Belogorsky, Blagoveshchensky, Zavitinsky, Ivanovsky, Konstantinovsky, Mikhailovsky, Oktyabrsky, Svobodnensky, Seryshevsky and Tambovsky.

These districts have a share of suitable land area equal to more than $60 \%$ of the total area of the district (Fig. 1). The pheasant does not constantly inhabit the 5 northern regions, 
where it is not recorded at all, or flyings are recorded in some years. The share of the area suitable for pheasant habitat in these areas is less than $4 \%$. The settlement of the pheasant in the northern regions of the region depends on human economic activity. With the decrease in acreage in the central regions of the region, it became the main factor in the decline in the number of the species in these regions.

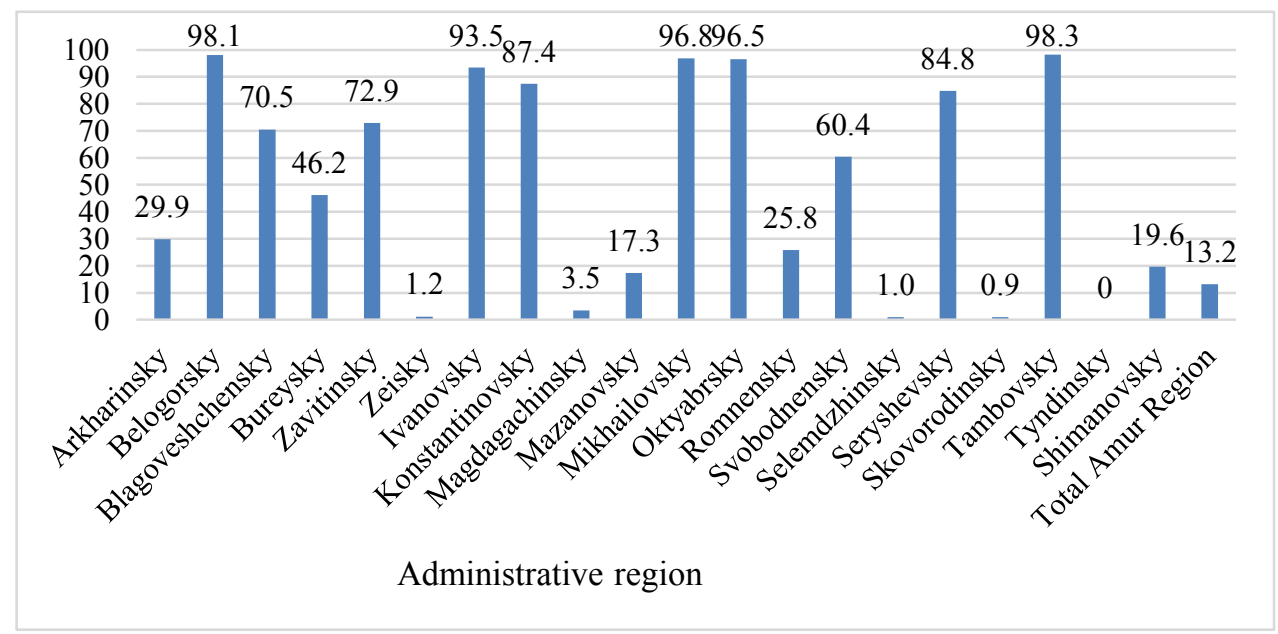

Fig. 1. The proportion of the area of suitable land for the habitation of the Manchurian pheasant of the total area of the district, \%.

The number of pheasants on the territory of the Amur Region is subject to great changes (Fig. 2). Until 2000, the data on the number of the species are inaccurate and fragmentary, due to the lack of full-fledged work on the registration of the number of the species. In 1987 , the number of pheasants in the region was about 35,000 individuals. The limiting factor in the number of pheasants on the territory of agricultural lands in the past was the uncontrolled application of fertilizers to the soil and the treatment of seeds and seedlings with pesticides. In the study area, the population of the Manchurian pheasant has been increasing since 2000. Since 2009, the number of pheasant has not decreased below the mark of 100,000 individuals.

In recent years, the number of the species has been steadily increasing and in 2020 , according to the data of registration works, it is 793147 individuals, which is more than 22 times more than those recorded in 1978 (about 35,000 individuals). In recent years, the increase in the number of the species is due to an increase in sown areas (from 790.8 thousand hectares in 2010 to 1180.2 thousand hectares in 2019 [1,2]), favorable weather conditions in the spring and summer periods, little snow winters and the conduct of biotechnical activities by employees of hunting farms and specially protected natural areas. 


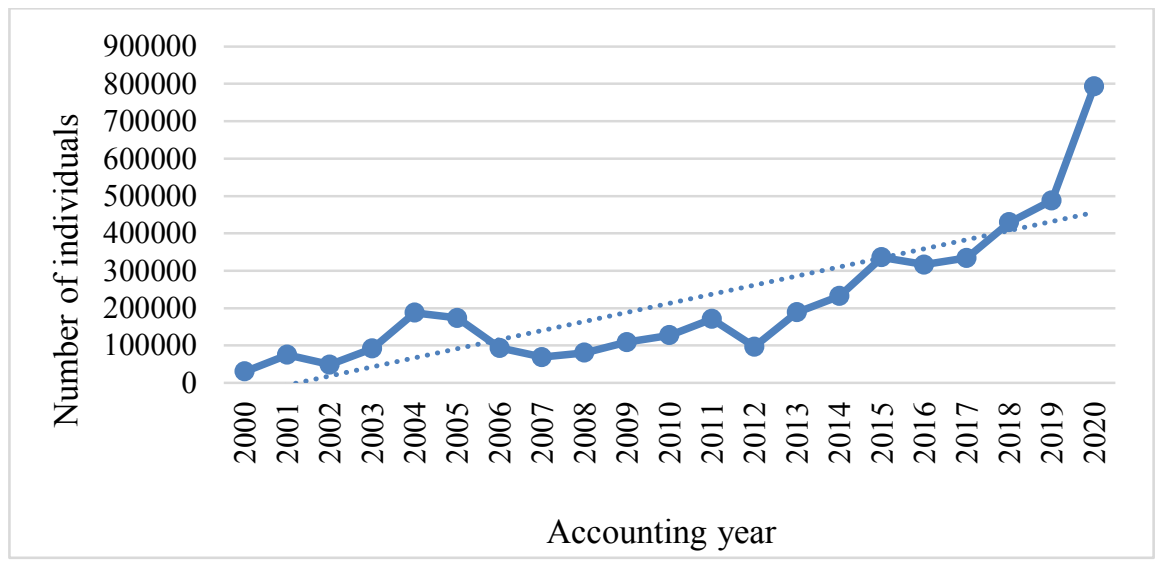

Fig. 2. Population dynamics of the Manchurian pheasant (Phasianus colchicus pallasi) on the territory of the Amur region (2000-2020).

The distribution of the average long-term number of pheasants over the territory of the Amur Region shows that about $50 \%$ of the species population lives in 5 administrative districts (Arkharinsky, Belogorsky, Blagoveshchensky, Ivanovsky and Oktyabrsky) (Fig. 3 ). According to the data on the number of hunting resources for 2019, the highest density of pheasant (more than 150 animals / 1 thousand hectares) was noted on the territory of six administrative districts - Arkharinsky, Belogorsky, Ivanovsky, Konstantinovsky, Mazanovsky and Tambovsky.

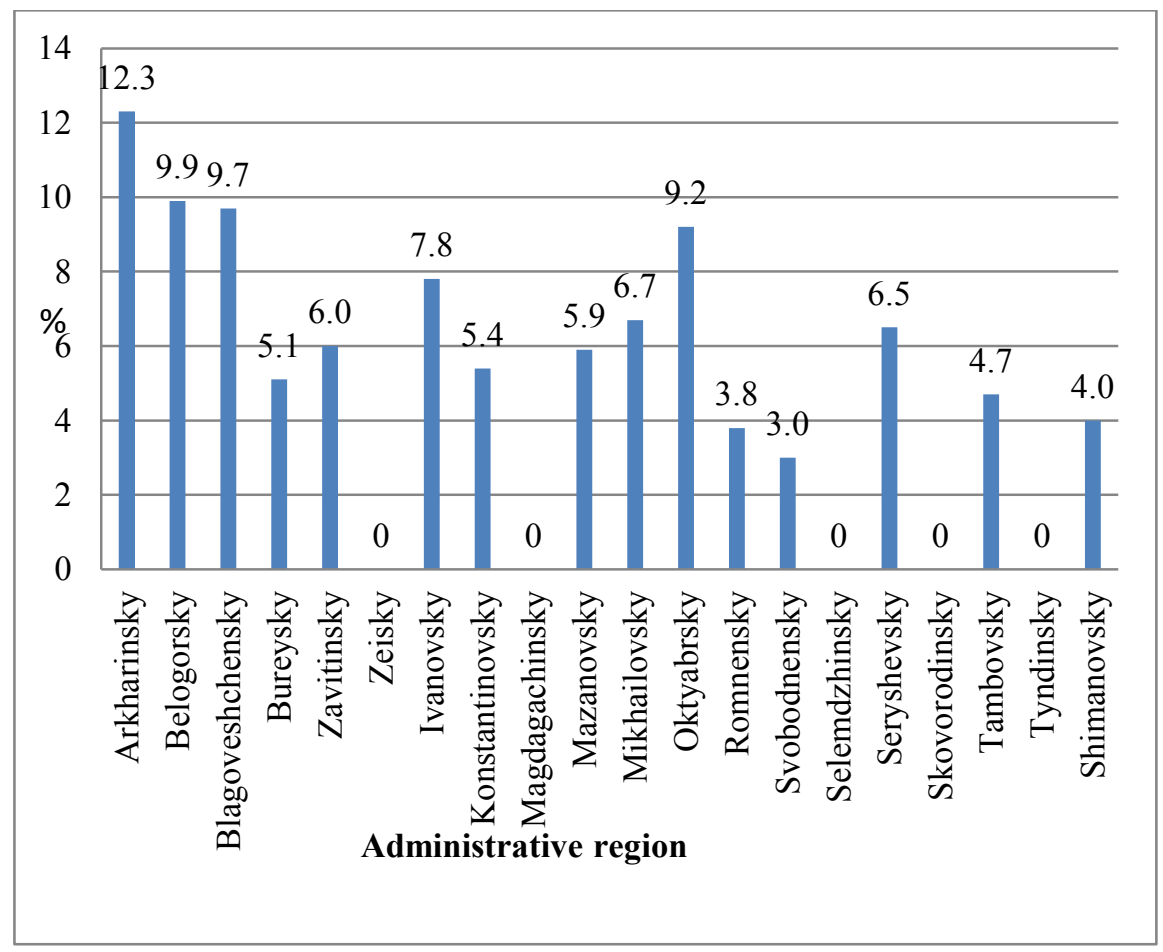

Fig. 3. Population distribution of the Manchurian pheasant (Phasianus colchicus pallasi Rothschild, 1903 ) in the administrative districts of the Amur region, \% (on average over 20 years). 
For habitation, pheasants prefer floodplain forests in the valleys of rivers and lakes, overgrown with poplar, willows with dense undergrowth and tall grasses, or bush vegetation. Dense littered floodplain forests are the main shelters for pheasants and have good nest-protective conditions. The area of such lands within the habitat of the species is 122.44 thousand hectares. An important factor for the pheasant's habitat is the availability of trees and shrubs. This is a class of young stands and shrubs, the area of which is 364.86 thousand hectares.

The development of agriculture with an increase in cultivated areas creates good feeding conditions for the pheasant. The area of such lands is 2157.13 thousand hectares. The landscape favorable for pheasants is a terrain with a pronounced mosaic of land. It can be deciduous reed forests surrounded by agricultural sowing fields. Hunting grounds of the Amur Region suitable for pheasant habitat, on average, belong to the II class of bonitet for the species. These lands are of above average quality, characterized by good forage and protective-nesting conditions. Such a high rating is achieved due to the good food supply in the study area, since most of the land is occupied by agricultural fields. But protectivenesting conditions can be attributed to average and every year their area decreases. This is due to the fact that more and more meadow-steppe lands are used by agricultural producers for arable land. Swampy meadows overgrown with tall grass are drained, providing pheasants with shelter from predators and good conditions for nesting.

Limiting factors. The number of the Manchu pheasant mainly depends on the weather and climatic conditions of a particular year. Especially, a cold, prolonged frost and wet spring has a detrimental effect on young growth. The population of pheasants during the period of incubation of eggs and hatching of chicks is adversely affected by temperature extremes, the presence and abundance of precipitation, wind, as well as predators with a high number of birds in habitats (common fox (Vulpes vulpes), raccoon dog, goshawk, etc.). Pheasants are easily affected by Newcastle disease. Pheasants are strongly attached to permanent habitats $[5,10]$. In this regard, factors of extreme natural character (fires, spring agricultural burns, floods, heavy snowfalls in spring and moisture) also have a limiting effect on the population of the Manchurian pheasant. A large number of places suitable for protection and nesting are destroyed by fires, which occur twice a year in agricultural lands and in the spring period coincide with the nesting period of pheasants. Anthropogenic pressure, especially poaching (many pheasants are caught illegally), cause a considerable share of harm.

The economic value and use of the pheasant. The development of pheasant resources in the hunting grounds of the Amur Region was not carried out constantly. So, in the mid-50s of the XX century, hunting was closed for a long time due to a decrease in the population of the species. In 1991, pheasant hunting was resumed and hunting was opened on the territory of three districts of the Amur Region: Blagoveshchensky, Ivanovsky and Tambovsky. Thereafter, the closure of hunting was noted several more times for one season due to a decrease in the population size due to unfavorable previous winter weather conditions.

Currently, the Manchurian pheasant is one of the important hunting and commercial species of hunting resources for the hunting industry of the Amur Region. Pheasant hunting is becoming more and more popular every year. In the central and southern administrative districts of the Amur Region, sports hunting for males is carried out in the autumn-winter period. Thus, the legal catch of the Manchurian pheasant in the Amur Region ranges from 3 to 12 thousand individuals, which, despite the significant illegal seizure, does not exhaust the resources.

In recent years, 6 hunting farms have organized pheasant hunting on the territory of the Amur Region (Table). At the same time, on the territory of the hunting grounds of the Amur regional public organization "Russian Association of Public Associations of Hunters 
and Fishermen" (AROO "RAOOOiR"), most of the pheasants in the region are hunted (over $92 \%$ ). This is due to the fact that the main lands of this organization are located on the Zeisko-Bureinskaya plain, where the bulk of the species population lives in the Amur region.

The number of hunted pheasants in recent years has been increasing in proportion to the increase in the number of the species. So, according to the data of 2015-2019, from 18144 individuals (2015) to 29000 individuals (2019) are hunted in the hunting farms of the Amur Region, which is $5.9-7.8 \%$ of the annual number of the species.

Unfortunately, at present, hunting products remain invaluable and are used only for personal purposes by members of the hunters' families. There is no purchase of wild animal meat from the population. But, for example, in 2019, the livestock sector of agriculture in the Amur Region produced 22,700 tons of poultry meat [1]. With the average indicators of the mass of processed carcasses of male pheasants obtained by us $(n=7)$, taken in the lands of the Amur Region in the winter period of $871.3 \mathrm{~g}$ and during the harvest in the hunting season of 2019, 29,000 individuals, the mass of meat obtained from the population of the species is 25,3 tons. That is $0.1 \%$ of poultry meat produced by agriculture.

Table 1. Information on the production of the Manchurian pheasant in the hunting grounds of the Amur Region (2015-2019).

\begin{tabular}{|c|c|c|c|c|c|c|c|}
\hline \multirow[b]{2}{*}{ Year } & \multirow[b]{2}{*}{ Index } & \multicolumn{6}{|c|}{ Hunting farm } \\
\hline & & 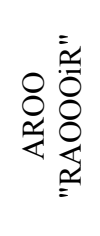 & 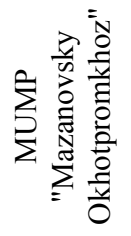 & 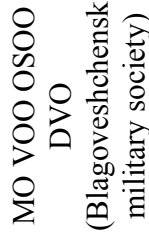 & 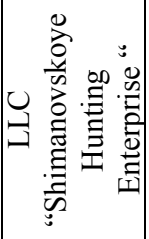 & 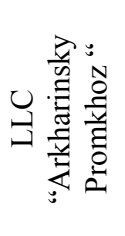 & 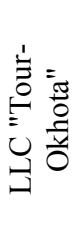 \\
\hline \multirow{2}{*}{$\frac{n}{2}$} & $\begin{array}{l}\text { Number of issued } \\
\text { permits for catching } \\
\text { pheasant, pieces }\end{array}$ & 6000 & - & - & - & - & 350 \\
\hline & $\begin{array}{l}\text { Number of birds } \\
\text { caught, individuals }\end{array}$ & 17640 & - & - & - & - & 504 \\
\hline \multirow{2}{*}{$\stackrel{0}{\circ}$} & $\begin{array}{l}\text { Number of issued } \\
\text { permits for catching } \\
\text { pheasant, pieces }\end{array}$ & 4700 & - & 340 & - & 100 & 350 \\
\hline & $\begin{array}{l}\text { Number of birds } \\
\text { caught, individuals }\end{array}$ & 19643 & - & 917 & - & 100 & 624 \\
\hline \multirow{2}{*}{ 홍 } & $\begin{array}{l}\text { Number of issued } \\
\text { permits for catching } \\
\text { pheasant, pieces }\end{array}$ & 3409 & - & 350 & - & 118 & 300 \\
\hline & $\begin{array}{l}\text { Number of birds } \\
\text { caught, individuals }\end{array}$ & 16030 & - & 903 & - & 118 & 313 \\
\hline \multirow{2}{*}{$\stackrel{\infty}{\stackrel{\sim}{\sim}}$} & $\begin{array}{l}\text { Number of issued } \\
\text { permits for catching } \\
\text { pheasant, pieces }\end{array}$ & 3954 & - & 400 & - & 110 & 300 \\
\hline & $\begin{array}{l}\text { Number of birds } \\
\text { caught, individuals }\end{array}$ & 19277 & - & 896 & - & 110 & 319 \\
\hline \multirow{2}{*}{ 롱 } & $\begin{array}{l}\text { Number of issued } \\
\text { permits for catching } \\
\text { pheasant, pieces }\end{array}$ & 6918 & 407 & 450 & 4 & 40 & 300 \\
\hline & $\begin{array}{l}\text { Number of birds } \\
\text { caught, individuals }\end{array}$ & 26104 & 1501 & 1011 & 35 & 30 & 319 \\
\hline
\end{tabular}


With the planned monitoring of the pheasant population in the hunting grounds of the Amur Region and the timely implementation of measures to maintain birds during periods with critical weather conditions for them, the number of the species can be maintained at the current level. This will enable hunting farms to fully use the population of the species, and the population to receive full-value, dietary, environmentally friendly meat products.

\section{Conclusion}

The resources of the Manchurian pheasant in the Amur Region are significant and amount to 793.1 thousand individuals, of which 290.0-300.0 thousand individuals of ecologically clean products can be harvested annually without damage to reproduction. The level of development of hunting birds in the Amur Region in some territories does not reach even half of the possible. Remote, hard-to-reach areas are still not being developed, there is no scientifically grounded organization and control of hunting, the withdrawal is mainly aimed at hunting birds in the most accessible areas, which negatively affects the state of resources. The so-called illegal hunting is widespread. The main reason for illegal mining is the lack of a reasoned system for managing resources and their withdrawal.

\section{References}

1. Amurskaya oblast' v cifrah: Kratkij statisticheskij sbornik Amurstat, 212 (2020)

2. Amurskij statisticheskij ezhegodnik 2019: Statisticheskij sbornik, Amurstat. 375 (2019)

3. O.S. Dyadchenko Ekologicheskie svojstva estestvennyh lesnyh soobshchestv yuzhnoj chasti Zejsko-Bureinskoj ravniny Ohrana i racional'noe ispol'zovanie lesnyh resursov: materialy VI mezhdunarodnogo foruma, 320-325 (2013)

4. P. V. Fisenko Izuchenie fazana obyknovennogo (Phasianus colchicus Linnaeus, 1758) na Dal'nem Vostoke Rossii Vestnik Dal'nevostochnogo otdeleniya Rossijskoj akademii nauk, 143-148 (2010)

5. Hill D., Robertson P. The pheasant ecology, management and conservation. Oxford: BSP Professional Books, 282 (1988)

6. E. A. Koblik, Ya. A. Red'kin, Yu V Arhipov, Spisok ptic Rossijskoj Federacii. Tovarishchestvo nauchnyh izdanij KMK. 256 (2006)

7. G. E. Larina, E. R. Gorr Landshaftno-jekologicheskoe obosnovanie sel'skohozyajstvennyh ugodij, raspolozhennyh na territorii Zejsko-Bureinskoj ravniny Amurskoj oblasti Vestnik Kemerovskogo gosudarstvennogo universiteta. 2, 1 (58), 78 82 (2014)

8. Y. Liu, S Liu, N Zhang, D Chen, P Que, N Liu Genome Assembly of the Common Pheasant Phasianus colchicus, A Model for Speciation and Ecological Genomics. Genome Biol Evol. 11(12), 3326-3331. (2019) doi: 10.1093/gbe/evz249.

9. V. A. Nechaev, T V Gamova Pticy Dal'nego Vostoka Rossii (annotirovannyj kata-log). 564 (2009)

10. M W Ridley, D A Hill Social organization in the pheasant (Phasianus colchicus): harem formation, mate selection and the role of mate guarding J. Zool. 211, 619-630 (1987)

11. S. Sandakova, A. Toushkin, O. Matveeva, A. Toushkina, Number and distribution of Amur region hunting birds (Tetraonidae) using GIS cartographic visualization methods Forestry Ideas 25, 1 (57), 91-118. (2019) 
12. S L Sandakova, A A Toushkin, O N Shcherbakova, A F Toushkina. CHislennost' naseleniya i osobennosti pitaniya man'chzhurskogo podvida fazana (Phasianus colchicus pallasi) v Amurskoj oblasti Pticy i sel'skoe hozyajstvo: mater. I Mezhd. ornitol. Konf, 263-268 (2015)

13. V. Senchik, N. S. Kuharenko, I E Sosnovskij. Harakteristika zimnih stacij sibirskoj kosuli (Capreolus pygargus Pall) na Zejsko-Bureinskoj ravnine, Izvestiya Nizhnevolzhskogo agrouniversitetskogo kompleksa: Nauka i vysshee professional'noe obrazovanie, 1 (53),189-196(2019)

14. B.K. Shtegman Osnovy ornitogeograficheskogo deleniya Palearktiki. Fauna SSSR. M. L. Izd-vo AN SSSR, 156, (1938)

15. L.S. Stepanyan Konspekt ornitologicheskoj fauny SSSR 728, (1990)

16. A.A. Toushkin, O.A Matveeva. Znachenie relochnyh lesov Zejsko-Bureinskoj ravniny dlya migriruyushchih vidov ptic v vesennij period. Geoekologiya i prirodopol'zovanie: aktual'nye voprosy nauki, praktiki i obrazovaniya Materialy Vserossijskoj nauchnoprakticheskoj yubilejnoj konferencii s mezhdunarodnym uchastiem, 230-233 (2018)

17. A.A. Toushkin., A.F. Toushkina O.A Matveeva Dinamika chislennosti i hozyajstvennoe ispol'zovanie populyacii man'chzhurskogo fazana, 1 (53), 84-90 (2020) 